
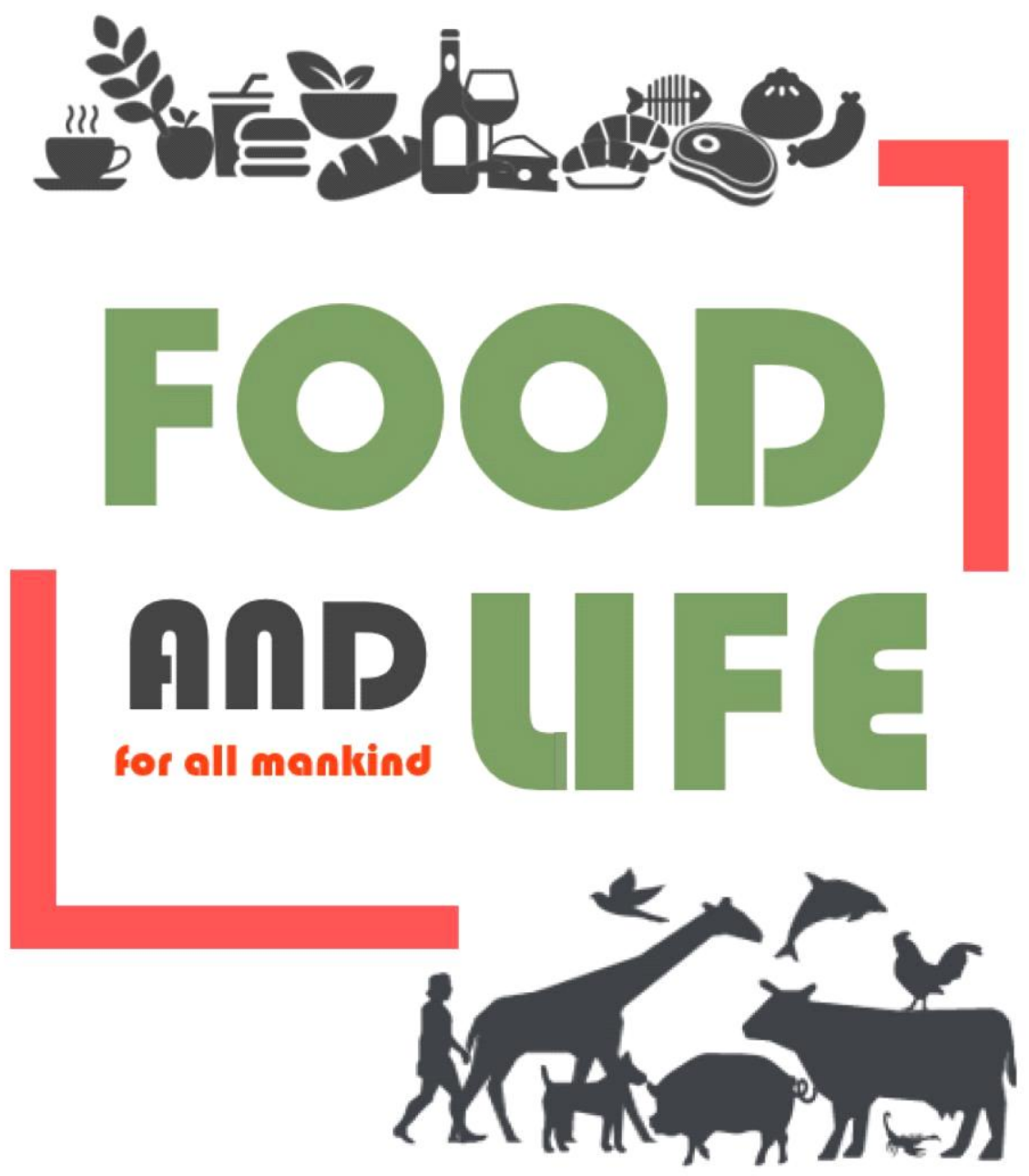

The Food and Life has published all type articles such as research articles, review articles, survey articles, research note, short communication or editorial since 2020. It covers the all scientific and technological aspects of food and life science.

\title{
https://www.foodnlife.org
}




\title{
유색 파프리카의 영양성분
}

\author{
류아름 ${ }^{1}$, 강민철$^{2}$, 홍정선 $^{2}$, 최정희 $^{3}$, 최윤상 ${ }^{2}$, 최희돈,* \\ 1한국식품연구원 식품융합인프라팀 \\ 2한국식품연구원 가공공정연구단 \\ 3한국식품연구원 안전유통연구단
}

\section{Nutritional components of colored paprika}

\author{
A-Reum Ryu', Min-Cheol Kang², Jung Sun Hong², Jeong Hee Choi ${ }^{3}$, Yun-Sang Choi², Hee-Don Choi ${ }^{2 *}$ \\ ${ }^{1}$ Food Convergence Infrastructure Team, Korea Food Research Institute, Wanju 55365, Korea \\ ${ }^{2}$ Research Group of Food Processing, Korea Food Research Institute, Wanju 55365, Korea \\ ${ }^{3}$ Research Group of Safety and Distribution, Korea Food Research Institute, Wanju 55365, Korea
}

\begin{abstract}
This study was conducted to examine the nutritional components of three different colored varieties of paprika-the red, the orange, and the yellow. Their nutritional value was investigated based on the approximate composition of free sugar, organic acid, free amino acid, fatty acids, vitamins, and mineral content. All 3 paprika varieties were rich in the free sugars-fructose and glucose, with red paprika (RP) having the highest sugar content. Amongst organic acids, the succinic acid content in RP was 3.6-5.3 times higher than orange paprika (OR) and yellow paprika (YP). Aspartic acid and glutamic acid were highest among the major free amino acids in all the paprika varieties, with the lowest content in the RP. Altogether, 6 saturated fatty acids and 4 unsaturated fatty acids were detected; the former were highest in the RP while the latter were highest in the $\mathrm{OR}$ and the YP varieties. YP and RP contained significantly higher content of vitamin $C$ and vitamin $E$ respectively, in comparison to OR. The colored paprika were rich in the following minerals, with significantly high content in the YP: potassium〉phosphorus〉magnesium. In conclusion, the findings indicate a difference in the nutritional composition of the colored varieties of paprika that can potentially be used as an index affecting the consumer consumption.
\end{abstract}

Keywords: colored paprika, nutritional components, nutritional characteristics, mineral, vitamin

\section{서 론}

파프리카(Capsicum annuum L.)는 가지과(Solanaceae)에 속 하는 작물로(Jeong et al., 2006), 아시아, 북아메리카, 남부 및 중부 유럽 그리고 열대 아프리카 등 전 세계적으로 따뜻한 기 후 지역에서 재배되고 있다(Baenas et al., 2019). 파프리카 (paprika)의 어원은 희랍어로 sweet pepper와 bell pepper라고도 불리는데(Lee et al., 2016), 우리나라에서는 매운맛이 없는 sweet pepper를 파프리카라고 하며(Jung and Hong, 2017), 국내에서는 1990년대 초부터 재배되기 시작하였다(Joung et al., 2018).

최근에는 건강에 대한 관심의 증가로 자연적인 식품에 대한 소비자의 요구가 높아지면서, 파프리카와 토마토 등과 같은 기 능성을 가진 농산물의 수요가 증가하고 있다(Jung and Hong,
2017). 파프리카는 수분함량이 $90 \%$ 이상으로, 당도가 높아서 주로 가공되지 않은 샐러드로 활용되거나(Park et al., 2014), 다 양한 색상을 가지고 있어서(Bae et al., 2018) 식품 산업에서는 가공 제품에 천연 착색제로 사용된다(Martín et al., 2017). 파프 리카의 색은 품종에 따라 빨간색, 노란색 및 초록색 등 다양한 색을 가지고 있고(Kang et al., 2021), 드물게는 흰색, 보라색, 파란색 그리고 갈색도 있지만(Faustino et al., 2007), 이 중에서 빨간색이 전체 파프리카 중에서 약 $40 \%$ 를 차지하고 있다 (Jeong et al., 2006). 파프리카의 다양한 색상은 소비자의 소비 에 영향을 주는 주요 요인으로(Kim et al., 2016c), 소비자들의 컬러 푸드에 대한 관심이 높아지면서 파프리카를 구매하는 소 비자들은 한 가지색보다는 다양한 색상의 파프리카에 대한 선

"Corresponding author : Hee-Don Choi. Research Group of Food Processing, Korea Food Research Institute, Wanju 55365, Korea. Tel: +82-63-219-9013, Fax: +82-63-219-9876, E-mail: chdon@kfri.re.kr

This is an Open-Access article distributed under the terms of the Creative Commons Attribution Non-Commercial License which permits unrestricted non-commercial use, distribution, and reproduction in any medium, provided the original work is properly cited (http://creativecommons.org/licenses/by-nc/4.0/). 
호도가 높다고 보고되고 있다(Kim et al., 2017). 파프리카는 chlorophyll 등 20개 이상의 색소를 함유하고 있고(Choi et al., 2020), 다양한 색은 숙성 중 생성된 carotenoid에 의해 형성되 는데(Topuz et al., 2009), 붉은색 파프리카의 주요 carotenoid는 capsanthin과 capsorbin, 노란색과 초록색 파프리카에는 lutein, 주 황색 파프리카에는 $\beta$-carotene이 주로 함유되어 있다(Kim et al., 2016b; Kim et al., 2018). Capsanthin, lutein 및 $\beta$-carotene이 함유 된 파프리카는 고유의 색상에 따라 눈 건강 및 동맥경화 예방 등 다양한 생리활성 효능 등이 보고되고 있다(Kim et al., 2011a).

파프리카는 carotenoid 이외에도 vitamin, mineral, tocopherol, flavonoid 및 phenolic compounds가 풍부하게 함유되어 있어 phytochemical 물질의 좋은 급원이 될 수 있는 과채류이며 (Kaur et al., 2020; Kim et al., 2011b), 이러한 화합물은 항산화 효과를 가지므로 인체에서 유해한 산화반응을 감소시켜 암 및 심혈관 질환과 관련된 다양한 질병을 예방할 수 있다고 알려져 있다(Sun et al., 2007). 이에 따라 어떤 색을 가진 파프리카를 섭취하느냐에 색마다 지닌 효능이 다를 수 있지만(Kim et al., 2011a), 색상에 따른 파프리카의 기초적인 영양성분에 관한 연 구는 보고된 바가 없다. 따라서 본 연구에서는 국내산 3가지 빨간 색, 주황색 그리고 노란색의 파프리카의 일반성분, 유리당, 유기 산, 아미노산, 지방산, 비타민 그리고 무기질의 영양성분을 분석하 여 색상에 따른 영양학적인 차이를 비교· 분석하고자 하였다.

\section{재료 및 방법}

\section{재료}

유색 파프리카는 전라북도 김제시에 소재한 스마트팜에서 동일한 재배조건으로 재배된 빨간색 파프리카(red paprika, $\mathrm{RP}$ ), 주황색 파프리카(orange paprika, OR) 그리고 노란색 파프 리카(yellow paprika, YP)를 과피색이 $90 \%$ 이상 착색되는 관행 완숙기에 수확하였다. 파프리카는 꼭지와 씨를 제거하여 가식 부위만을 이용하였으며, 세척하여 동결시킨 후 동결건조기 (PVTFD 100R, Ilshinbi obase, Dongducheon, Korea)를 사용하 여 건조하였다. 동결 건조된 파프리카는 후드믹서(HMF-3260S, Hanil Electric, Seoul, Korea)로 분쇄하여 냉동 보관하면서 분 석에 이용하였다.

\section{분석항목 및 방법}

\section{일반성분}

파프리카의 일반성분 분석은 생과의 가식 부위만을 이용하 여 표준 시험법인 AOAC법(AOAC, 2000)으로 수행하였다. 수 분은 $105^{\circ} \mathrm{C}$ 상압가열 건조법, 조단백의 함량은 단백질 분석기 측정법, 조지방은 에테르 추출법, 그리고 조회분은 $550^{\circ} \mathrm{C}$ 직접
회화법으로 분석하였고, 탄수화물은 100 에서 수분, 조단백, 조 지방, 조회분 함량을 뺀 값으로 하였다.

\section{유리당}

파프리카 $0.5 \mathrm{~g}$ 에 $50 \%$ ethanol을 가한 후 $85^{\circ} \mathrm{C}$ 에서 25 분간 가온하여 당류를 추출하였다. 추출물은 $25^{\circ} \mathrm{C}$ 로 냉각한 후 $15,000 \times \mathrm{g}$ 에서 15 분간 원심 분리하였고, $0.2 \mu \mathrm{m}$ membrane filter로 여과한 후 분석하였다. 분석은 HPLC(SP3023, Shiseido, Tokyo, Japan)로 RI detector를 사용하여 검출하였다. 컬럼은 asahipak NH2P-50 4E(4.6×250 mm)을 사용하였고, 유속은 1.0 $\mathrm{mL} / \mathrm{min}$ 조건으로 실시하였으며, 이동상은 acetonitrile과 water 를 80:20 (v/v)의 비율로 사용하여 분석하였다.

\section{유기산}

유기산 분석은 유리당 분석과 같은 방법으로 제조한 추출물 을 HPLC(SP3023, Shiseido)로 PDA detector로 분석하였다. Column은 supelcogel C- $610 \mathrm{H}(7.8 \times 300 \mathrm{~mm})$ 를 사용하였고, 컬 럼 온도는 $30^{\circ} \mathrm{C}$, 유속은 $0.5 \mathrm{~mL} / \mathrm{min}$ 조건으로 실시하였으며, 이 동상은 $0.1 \%$ phosphate buffer를 사용하여 분석하였다.

\section{아미노산}

파프리카의 구성 아미노산은 아미노산 자동분석기(L-8900, Hitachi, Tokyo, Japan)를 이용하여 측정하였다. Column은 ion exchange column을 이용하였고, $440 \mathrm{~nm}$ 와 $570 \mathrm{~nm}$ 에서 측정하 였다. 표준용액은 아미노산 표준용액(AAS18, Sigma-Aldrich, St. Louis, MO, USA)을 $0.02 \mathrm{~N} \mathrm{HCl}$ 로 10, 25, 50, 100, 250배 희석하여 사용하였다.

\section{지방산}

동결 건조된 파프리카는 p-ether에 침지하여 24시간 방치한 후 용해된 지방을 농축하였다. 농축액에 $2 \mathrm{~mL}$ 의 $0.5 \mathrm{~N} \mathrm{NaOH} /$ $\mathrm{MeOH}$ solution을 넣고 $100^{\circ} \mathrm{C}$ heating block에서 10 분간 가열시 킨 후 냉각시켰다. 냉각 후 $14 \% \mathrm{BF} 3 / \mathrm{MeOH}$ 을 $2 \mathrm{~mL}$ 넣고 $100^{\circ} \mathrm{C}$ 에서 10 분간 가열 후 냉각시켰다. 냉각 후 internal standard로 isooctane을 $2 \mathrm{~mL}$ 넣고 혼합하여 10 분간 정치한 후, $2 \mathrm{~mL}$ 의 포 화식염수를 넣고 다시 10 분간 정치시켜 얻은 상등액을 분석하 였다. 분석은 GC-FID(Agilent Technologies 7890A, Santa Clara, $\mathrm{CA}, \mathrm{USA})$ 로 분석하였다. 컬럼은 $\mathrm{HP} \operatorname{FFAP}(0.32 \mathrm{~mm} \times 30 \mathrm{~m}$ I.D., $0.52 \mu \mathrm{m}$ film thickness)을 사용하였고, 컬럼 온도는 $100^{\circ} \mathrm{C}$ (2분), $4^{\circ} \mathrm{C} / \mathrm{min}, 230^{\circ} \mathrm{C}$ (20분)로 하였으며, 유속은 $1.5 \mathrm{~mL} / \mathrm{min}$ 조 건으로 하였다.

\section{비타민}

비타민 C 추출은 Kim 등(2018)의 방법을 이용하였다. 파프 
리카 분말 $1 \mathrm{~g}$ 을 $1 \mathrm{~mL}$ 의 $10 \% \mathrm{KH}_{2} \mathrm{PO}_{4}$ 용액에 첨가하여 10 분 간 현탁시킨 후, $5 \% \mathrm{KH}_{2} \mathrm{PO}_{4}$ 용액으로 $100 \mathrm{~mL}$ 로 정용하였다. 추출물은 $0.45 \mu \mathrm{m}$ membrane filter(Millipore, Bedford, MA, USA)로 여과하여 분석하였다. 분석은 HPLC(SP3023, Shiseido) 로 분석하였다. 컬럼은 YMC-Pack polyamine $I I(4.6 \times 250 \mathrm{~mm}$, $\mathrm{S}-5 \mu \mathrm{m}, 12 \mathrm{~nm}$ )를 사용하였고, 컬럼 온도는 $30^{\circ} \mathrm{C}$, 유속은 1.0 $\mathrm{mL} / \mathrm{min}$ 조건으로 실시하였으며, 이동상은 $0.05 \mathrm{M} \mathrm{KH}_{2} \mathrm{PO}_{4}$ 와 acetonitrile를 60:40(v/v)의 비율로 사용하여 UV detector 254 $\mathrm{nm}$ 에서 분석하였다.

비타민 E 추출은 Kim 등(2011a)의 방법을 이용하였다. 파프리 카 시료 $1 \mathrm{~g}$ 에 $5 \mathrm{~mL}$ 의 methanol을 가한 후 용액[dichloroethane/ $\mathrm{MeOH}(6: 1, \mathrm{v} / \mathrm{v})] 12 \mathrm{~mL}$ 를 넣고 $4^{\circ} \mathrm{C}$ 에서 30 분 반응시켰다. 분 리된 dichlorethane은 $2 \% \mathrm{Na}_{2} \mathrm{SO}_{4}$ 를 첨가하여 수분을 제거 후 감압 농축하였고, 농축액은 $\mathrm{MeOH}$ 에 녹여 분석하였다. 분석은 HPLC(L-2200U, Hitachi)를 이용하여 fluorescence detector로 excitation $298 \mathrm{~nm}$, emission $325 \mathrm{~nm}$ 에서 검출하였다. 컬럼은 reverse phase $\mathrm{C} 18(5 \mu \mathrm{m}$ particle size, $4.6 \times 150 \mathrm{~mm})$ 을 사용하였 고, 유속은 $1.0 \mathrm{~mL} / \mathrm{min}$ 조건으로 실시하였다.

\section{무기질}

무기질 분석은 Kim 등(2016a)의 방법을 이용하였다. 동결건 조 된 파프리카 분말에 용액 $\left(\mathrm{H}_{2} \mathrm{O}_{2}: \mathrm{HNO}_{3}=2: 8\right)$ 을 가하여 분해한 후 $\mathrm{Ca}, \mathrm{Cu}, \mathrm{Fe}, \mathrm{K}, \mathrm{Mg}, \mathrm{Mn}, \mathrm{Na}, \mathrm{P}$ 및 $\mathrm{Zn}$ 을 ICP-OES(Avio 500, Perkin Elmer, Waltham, MA, USA)으로 측정하였다.

\section{통계처리}

실험 결과의 통계 분석은 SPSS statistics version 20(IBM, Armonk, NY, USA) program으로 one-way ANOVA로 분석하 여 평균 \pm 표준편차로 나타내었고, Duncan's multiple range test 로 $p<0.05$ 수준에서 시료 간의 유의성을 검증하였다.

\section{결과 및 고찰}

\section{유색 파프리카의 일반성분}

유색 파프리카의 일반성분 측정결과는 각각 Fig. 1 , Table 1 에 나타내었다. 빨간색, 주황색 그리고 노란색의 3 가지 유색 파 프리카를 동결 건조하였을 때 고유의 색을 유지하였고, 색의 변 화는 나타나지 않았다. 유색 파프리카의 수분 함량은 $91.45 \%$ $91.87 \%$ 로 나타났고, 지방은 $0.19 \%-0.29 \%$, 단백질은 $0.70 \%-$ $0.90 \%$, 회분은 $0.42 \%-0.48 \%$ 그리고 탄수화물은 $6.52 \%-6.95 \%$ 로 나타났다. 회분의 경우 $\mathrm{OP}$ 가 RP와 $\mathrm{YP}$ 에 비해 유의적으로 높게 나타났지만, 수분, 지방 그리고 단백질의 경우 색상에 따 른 유의적인 차이는 없었다. Park 등(2020)은 파프리카의 수분 함량은 92.7\%로 보고하였고, Jeong 등(2006)은 파프리카의 품 종별 일반성분을 분석한 결과, 수분과 조지방은 품종별로 큰 함량 차이를 나타내지 않았다고 보고하여 본 결과와 유사한 것 으로 나타났다.

\begin{tabular}{|c|c|c|c|}
\hline & $\mathrm{RP}$ & OP & $\mathrm{YP}$ \\
\hline $\begin{array}{c}\text { Freeze-dried } \\
\text { paprika }\end{array}$ & & & \\
\hline
\end{tabular}

Fig. 1. Photograph of colored paprika in Korea. RP, red paprika; OP, orange paprika; YP, yellow paprika.

Table 1. Proximate composition of fresh colored paprika in Korea ( $\mathrm{g} / 100 \mathrm{~g}$ of fresh weight)

\begin{tabular}{cccc}
\hline & RP & OP & YP \\
\hline Moisture content & $91.87 \pm 0.17^{\mathrm{a}}$ & $91.45 \pm 0.01^{\mathrm{b}}$ & $91.74 \pm 0.00^{\mathrm{ab}}$ \\
Crude lipid & $0.29 \pm 0.03^{\mathrm{a}}$ & $0.23 \pm 0.05^{\mathrm{a}}$ & $0.19 \pm 0.01^{\mathrm{a}}$ \\
Crude protein & $0.90 \pm 0.00^{\mathrm{a}}$ & $0.90 \pm 0.00^{\mathrm{a}}$ & $0.70 \pm 0.00^{\mathrm{a}}$ \\
Crude ash & $0.42 \pm 0.00^{\mathrm{b}}$ & $0.48 \pm 0.02^{\mathrm{a}}$ & $0.44 \pm 0.00^{\mathrm{b}}$ \\
Carbohydrate & $6.52 \pm 0.21^{\mathrm{b}}$ & $6.95 \pm 0.02^{\mathrm{a}}$ & $6.95 \pm 0.01^{\mathrm{a}}$ \\
\hline
\end{tabular}

Each result is expressed as the mean \pm SD.

Different superscripts in the same row are significantly different at $\not<0.05$ by Duncan's multiple range test.

$\mathrm{RP}$, red paprika; OP, orange paprika; YP, yellow paprika. 


\section{유색 파프리카의 유리당}

유색 파프리카의 5 종 유리당 함량을 분석한 결과(Table 2), 총당 함량은 22.34-28.43 g/100 g으로 나타났다. 그 중 fructose (10.47-13.66 g/100 g)와 glucose(10.57-14.41 g/100 g)가 파프 리카를 구성하는 주요 구성 유리당으로 나타났고, sucrose는 0.28-1.30 g/100 g으로 소량 함유되어 있었다. 반면 lactose와 maltose는 검출되지 않았다. 주요 구성 유리당인 fructose와 glucose의 경우 색상에 따라서 RP, YP 그리고 OP 순으로 유의 적인 차이를 나타내어 RP가 단맛이 높아 샐러드용으로 섭취할 때 기호도가 더 높을 것으로 사료된다. Jeong 등(2006)은 품종 별 파프리카의 유리당 분석 결과, glucose( $1.36 \%-1.45 \%)$ 와 fructose $(0.06 \%-1.53 \%)$ 가 주요 유리당이고, sucrose $(0.02 \%-0.08 \%)$ 도 미량 함유되어 있었다고 보고하였고, $\mathrm{Ha}$ 등(2019)은 5품종의 파프리카 유리당 함량을 분석한 결과, fructose $(0.06 \%-1.53 \%)$ 와 glucose(1.36\%-1.45\%)가 주요 유리당으로 나타났고, 색상에 따 라서는 같은 빨간색 파프리카이지만 품종(Jacalo, nagano)에 따 른 함량의 차이가 많다고 보고하였다. 본 연구결과, 전체적으로 파프리카의 구성 유리당의 조성 및 함량비율은 유사한 경향을 보였다.

\section{유색 파프리카의 유기산}

유색 파프리카의 유기산 함량 분석 결과, malic acid는 98.15$108.07 \mathrm{mg} / 100 \mathrm{~g}$ 그리고 citric acid는 327.78-349.26 mg/100 g
으로 나타났으며, 색상에 따른 유의적인 차이는 없었다(Table 3). 반면 succinic acid의 경우 색상에 따른 유의적인 차이를 나 타내었는데 RP는 $626.66 \mathrm{mg} / 100 \mathrm{~g}$ 으로, $\mathrm{OP}(174.70 \mathrm{mg} / 100 \mathrm{~g})$ 그리고 $\mathrm{YP}(117.48 \mathrm{mg} / 100 \mathrm{~g})$ 보다 각각 3.6배, 5.3배 더 높게 나 타났다. Kim 등(2011)은 2가지 유색 파프리카의 유기산을 측정 한 결과, oxalic acid와 citric acid의 경우 빨간색 파프리카가 유 의적으로 높았고, malic acid와 fumaric acid의 경우 초록색 파 프리카가 유의적으로 더 높은 결과를 나타내어 유기산마다 차 이가 나타났다고 보고하였고, Jeong 등(2006)은 품종별 파프리 카의 유기산을 측정한 결과, tartaric acid, succinic acid 그리고 citric acid가 주로 높게 나타났고, 품종별에 따라 유기산 함량에 차이를 나타냈다고 보고하였다.

\section{유색 파프리카의 아미노산}

3 가지의 유색 파프리카의 아미노산 함량을 분석한 결과, 표 준 용액을 기준으로 총 16 종의 아미노산을 확인하였다(Table 4). 전체 아미노산 중 aspartic $\operatorname{acid}(1,786.89-2,491.07 \mathrm{mg} / 100$ $\mathrm{g})$, glutamic acid(1,372.07-1,960.94 mg/100 g) 그리고 lysine (431.80-459.83 mg/100 g)이 55.2\%-60.4\%를 나타내어 파프리 카의 주요 구성 아미노산으로 나타났다.

Jeong 등(2006)의 보고에 의하면 색상이 다른 품종인 파프리 카의 아미노산 측정결과, 빨간색과 주황색 품종의 경우 lysine, aspartic acid 및 glutamic acid가 주요 아미노산으로 나타났고,

Table 2. Free sugar content of colored paprika in Korea ( $\mathrm{g} / 100 \mathrm{~g}$ of dry weight)

\begin{tabular}{cccc}
\hline & $\mathrm{RP}$ & $\mathrm{OP}$ & $\mathrm{YP}$ \\
\hline Fructose & $13.66 \pm 0.41^{\mathrm{a}}$ & $10.47 \pm 0.37^{\mathrm{c}}$ & $11.68 \pm 0.25^{\mathrm{b}}$ \\
Glucose & $14.41 \pm 0.51^{\mathrm{a}}$ & $10.57 \pm 0.08^{\mathrm{c}}$ & $12.13 \pm 0.04^{\mathrm{b}}$ \\
Lactose & 0.0 & 0.0 & 0.0 \\
Sucrose & $0.36 \pm 0.01^{\mathrm{b}}$ & $1.30 \pm 0.11^{\mathrm{a}}$ & $0.28 \pm 0.01^{\mathrm{b}}$ \\
Maltose & 0.0 & 0.0 & 0.0 \\
Total & 28.43 & 22.34 & 24.09 \\
\hline
\end{tabular}

Each result is expressed as the mean \pm SD.

Different superscripts in the same row are significantly different at $\not<0.05$ by Duncan's multiple range test.

$\mathrm{RP}$, red paprika; OP, orange paprika; YP, yellow paprika.

Table 3. Organic acid content of colored paprika in Korea ( $\mathrm{mg} / 100 \mathrm{~g}$ of dry weight)

\begin{tabular}{cccc}
\hline & RP & OP & YP \\
\hline Malic acid & $108.07 \pm 7.24^{\mathrm{a}}$ & $98.15 \pm 3.72^{\mathrm{a}}$ & $98.26 \pm 1.35^{\mathrm{a}}$ \\
Citric acid & $327.78 \pm 14.62^{\mathrm{a}}$ & $349.26 \pm 5.02^{\mathrm{a}}$ & $335.34 \pm 8.60^{\mathrm{a}}$ \\
Succinic acid & $626.66 \pm 24.10^{\mathrm{a}}$ & $174.70 \pm 6.15^{\mathrm{b}}$ & $117.48 \pm 3.57^{\mathrm{c}}$ \\
\hline
\end{tabular}

Each result is expressed as the mean \pm SD.

Different superscripts in the same row are significantly different at $\not<0.05$ by Duncan's multiple range test.

$\mathrm{RP}$, red paprika; OP, orange paprika; YP, yellow paprika. 
Table 4. Free amino acids content of colored paprika in Korea (mg/100 $\mathrm{g}$ of dry weight)

\begin{tabular}{cccc}
\hline & RP & OP & YP \\
\hline Aspartic acid & $1,786.89 \pm 50.77^{\mathrm{b}}$ & $2,392.54 \pm 39.70^{\mathrm{a}}$ & $2,491.07 \pm 21.38^{\mathrm{a}}$ \\
Threonine & $315.53 \pm 2.72^{\mathrm{a}}$ & $336.58 \pm 15.55^{\mathrm{a}}$ & $257.97 \pm 2.57^{\mathrm{b}}$ \\
Serine & $323.68 \pm 26.73^{\mathrm{a}}$ & $328.35 \pm 8.72^{\mathrm{a}}$ & $363.04 \pm 13.65^{\mathrm{a}}$ \\
Glutamic acid & $1,372.07 \pm 21.35^{\mathrm{c}}$ & $1,960.94 \pm 42.21^{\mathrm{a}}$ & $1,696.04 \pm 19.22^{\mathrm{b}}$ \\
Proline & $73.01 \pm 7.76^{\mathrm{ab}}$ & $55.78 \pm 4.59^{\mathrm{b}}$ & $82.38 \pm 6.44^{\mathrm{a}}$ \\
Glycine & $274.03 \pm 6.41^{\mathrm{b}}$ & $299.35 \pm 2.84^{\mathrm{a}}$ & $306.29 \pm 4.25^{\mathrm{a}}$ \\
Alanine & $289.39 \pm 6.59^{\mathrm{c}}$ & $363.10 \pm 1.49^{\mathrm{a}}$ & $325.26 \pm 3.62^{\mathrm{b}}$ \\
Valine & $325.44 \pm 8.01^{\mathrm{b}}$ & $356.40 \pm 4.44^{\mathrm{a}}$ & $342.02 \mathrm{a} \pm 2.19^{\mathrm{b}}$ \\
Methionin & $12.58 \pm 0.61^{\mathrm{c}}$ & $22.93 \pm 0.21^{\mathrm{a}}$ & $17.95 \pm 1.50^{\mathrm{b}}$ \\
Isoleucine & $236.94 \pm 8.57^{\mathrm{a}}$ & $237.83 \pm 0.21^{\mathrm{a}}$ & $226.85 \pm 2.83^{\mathrm{a}}$ \\
Leucine & $362.37 \pm 26.83^{\mathrm{a}}$ & $399.43 \pm 0.25^{\mathrm{a}}$ & $379.61 \pm 5.41^{\mathrm{a}}$ \\
Tyrosine & $55.00 \pm 6.00^{\mathrm{a}}$ & $52.62 \pm 3.79^{\mathrm{a}}$ & $57.08 \pm 1.69^{\mathrm{a}}$ \\
Phenylalanine & $222.78 \pm 6.18^{\mathrm{b}}$ & $239.66 \pm 1.13^{\mathrm{a}}$ & $228.82 \pm 2.26^{\mathrm{ab}}$ \\
Lysine & $431.80 \pm 16.09^{\mathrm{a}}$ & $459.83 \pm 25.79^{\mathrm{a}}$ & $445.51 \pm 10.27^{\mathrm{a}}$ \\
Histidine & $129.68 \pm 2.61^{\mathrm{b}}$ & $142.88 \pm 0.87^{\mathrm{a}}$ & $130.13 \pm 1.54^{\mathrm{b}}$ \\
Arginine & $287.40 \pm 23.34^{\mathrm{a}}$ & $322.29 \pm 28.63^{\mathrm{a}}$ & $315.73 \pm 1.22^{\mathrm{a}}$ \\
\hline Total & $12,997.5$ & $15,945.9$ & $15,339.5$
\end{tabular}

Each result is expressed as the mean \pm SD.

Different superscripts in the same row are significantly different at $\not<0.05$ by Duncan's multiple range test.

$\mathrm{RP}$, red paprika; OP, orange paprika; YP, yellow paprika.

노란색 품종의 경우 lysine, aspartic acid 및 serine가 주요 아미 노산으로 나타났다고 보고하여 아미노산의 조성이 비슷하게 나타났다. 본 연구결과, 색상에 따라서 lysine은 유의적인 차이 가 없었지만, 전체 아미노산 중 $27.49 \%-32.49 \%$ 를 차지하는 aspartic acid의 경우 OP와 YP가 RP에 비해 유의적으로 높았 고, glutamic acid는 OP, YP 그리고 RP 순으로 유의적인 차이 를 나타내어 $\mathrm{OP}$ 가 다른 색상의 파프리카보다 아미노산의 함량 이 높은 경향을 나타냈다.

\section{유색 파프리카의 지방산}

유색 파프리카의 지방산 조성을 분석한 결과(Table 5), 포화 지방산 7종과 불포화지방산 4종이 함유되어 있었다. 전체 지방 산 중에서 포화지방산 함유량은 $24.49 \%-29.35 \%$ 그리고 불포 화지방산은 $69.4 \%-74.89 \%$ 로 나타났다. 포화지방산 중에서는 palmitic acid가 57.8\%-66.1\%로 가장 함유량이 높았고, myristic $\operatorname{acid}(9.30 \%-16.21 \%)$ 그리고 stearic $\operatorname{acid}(16.6 \%-20.32 \%)$ 순으로 나타났다. Lauric acid, behenic acid 및 lignoceric acid는 미량 함유되어 있는 것으로 나타났다. 색상에 따라 palmitic acid는 $\mathrm{RP}(16.98 \%)$ 가 $\mathrm{YP}(16.20 \%)$ 와 $\mathrm{OP}(15.34 \%)$ 보다 유의적으로 높 게 나타났고, lauric acid와 myristic acid 또한 같은 경향을 나타 내었다. 반면 behenic acid와 lignoceric acid의 경우 미량이지만

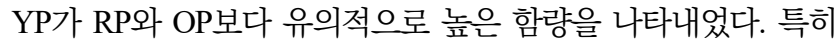
arachidic acid의 경우 RP에서는 $0.63 \%$ 로 미량 함유되어 있었 으나 OP와 YP에서는 검출되지 않았다. Matsufuji 등(1998)은 붉은색 파프리카의 주요 carotenoid인 capsanthin은 숙성되면서 주로 lauric acid, myristic acid 및 palmitic acid로 에스테르화된 다고 보고하였다. 따라서 RP가 다른 색의 파프리카보다 포화지 방산의 함량이 유의적으로 높게 나타난 것으로 사료된다.

불포화 지방산의 경우 linoleic acid가 $40.20 \%-44.51 \%$ 로 가 장 높았고, linolenic $\operatorname{acid}(25.77 \%-27.12 \%)$, oleic acid(1.31\%$3.52 \%)$ 및 palmitoleic acid(1.07\%-1.15\%) 순서로 분석되었다. 파프리카 색상에 따라서는 linoleic acid의 경우 $\mathrm{YP}(44.51 \%)$ 가 $\mathrm{OP}(43.87 \%)$ 와 $\mathrm{RP}(40.20 \%)$ 에 비해 유의적으로 높게 나타났다. 반면 linolenic acid의 경우 $\mathrm{OP}(27.12 \%)$ 가 유의적으로 가장 높 았고, $\mathrm{RP}(26.74 \%)$ 그리고 $\mathrm{YP}(25.77 \%)$ 순으로 분석되었다. Zaki 등(2013)의 보고에 의하면 수확시기에 따른 파프리카의 포화지방산 함량은 $11.4 \%-14.4 \%$ 이고, 불포화지방산은 $84.7 \%^{-}$ $88.6 \%$ 라고 하였고, 주요 지방산의 경우 불포화 지방산은 linoleic acid, 포화지방산은 palmitic acid라고 하였고, Jeong 등 (2006)은 품종에 따른 파프리카의 지방산을 분석한 결과, linoleic acid가 주요한 불포화 지방산으로 보고하여 주요 지방 산은 조성이 본 연구결과와 비슷한 결과를 나타내었다. 
Table 5. Fatty acids content of colored paprika in Korea (Composition ratio(\%)/100 g of fat)

\begin{tabular}{lccc}
\hline & $\mathrm{RP}$ & $\mathrm{OP}$ & $\mathrm{YP}$ \\
\hline Lauric acid (C12:0) & $1.35 \pm 0.11^{\mathrm{a}}$ & $0.68 \pm 0.06^{\mathrm{b}}$ & $0.25 \pm 0.00^{\mathrm{c}}$ \\
Myristic acid (C14:0) & $4.76 \pm 0.18^{\mathrm{a}}$ & $3.47 \pm 0.06^{\mathrm{b}}$ & $2.28 \pm 0.02^{\mathrm{c}}$ \\
Palmitic acid (C16:0) & $16.98 \pm 0.08^{\mathrm{a}}$ & $15.34 \pm 0.01^{\mathrm{c}}$ & $16.20 \pm 0.07^{\mathrm{b}}$ \\
Stearic acid (C18:0) & $4.89 \pm 0.07^{\mathrm{b}}$ & $5.15 \pm 0.01^{\mathrm{a}}$ & $4.79 \pm 0.02^{\mathrm{b}}$ \\
Arachidic acid (C20:0) & $0.63 \pm 0.02^{\mathrm{a}}$ & $0.0^{\mathrm{b}}$ & $0.0^{\mathrm{b}}$ \\
Behenic acid (C22:0) & $0.47 \pm 0.0^{\mathrm{b}}$ & $0.48 \pm 0.04^{\mathrm{b}}$ & $0.59 \pm 0.01^{\mathrm{a}}$ \\
Lignoceric acid (C24:0) & $0.27 \pm 0.01^{\mathrm{b}}$ & $0.22 \pm 0.01^{\mathrm{c}}$ & $0.38 \pm 0.00^{\mathrm{a}}$ \\
\hline Total saturated fatty acid & 29.35 & 25.34 & 24.49 \\
\hline Palmitoleic acid (C16:1) & $1.15 \pm 0.01^{\mathrm{a}}$ & $1.07 \pm 0.04^{\mathrm{b}}$ & $1.09 \pm 0.01^{\mathrm{ab}}$ \\
Oleic acid (C18:1) & $1.31 \pm 0.02^{\mathrm{c}}$ & $1.72 \pm 0.02^{\mathrm{b}}$ & $3.52 \pm 0.03^{\mathrm{a}}$ \\
Linoleic acid (C18:2) & $40.20 \pm 0.12^{\mathrm{c}}$ & $43.87 \pm 0.06^{\mathrm{b}}$ & $44.51 \pm 0.10^{\mathrm{a}}$ \\
Linolenic acid( $\alpha$ ) (C18:3) & $26.74 \pm 0.11^{\mathrm{b}}$ & $27.12 \pm 0.06^{\mathrm{a}}$ & $25.77 \pm 0.14^{\mathrm{c}}$ \\
\hline \multicolumn{1}{c}{ Total unsaturated fatty acid } & 69.4 & 73.78 & 74.89 \\
\hline \multicolumn{1}{c}{ Total } & $1.28 \pm 0.02^{\mathrm{a}}$ & $0.88 \pm 0.01^{\mathrm{b}}$ & $0.60 \pm 0.00^{\mathrm{c}}$ \\
\hline
\end{tabular}

Each result is expressed as the mean $\pm S D$.

Different superscripts in the same row are significantly different at $\not<0.05$ by Duncan's multiple range test.

$\mathrm{RP}$, red paprika; OP, orange paprika; YP, yellow paprika.

\section{유색 파프리카의 비타민}

유색 파프리카의 비타민 C 측정 결과(Table 6), $\mathrm{RP}(1,302.47$ $\mathrm{mg} / 100 \mathrm{~g})$ 및 $\mathrm{OP}(1,234.79 \mathrm{mg} / 100 \mathrm{~g})$ 는 비슷하게 나타났고, $\mathrm{YP}$ 가 $1,466.86 \mathrm{mg} / 100 \mathrm{~g}$ 으로 유의적으로 가장 높은 함량을 나 타내어 vitamin C의 좋은 급원으로 나타났다. Zaki 등(2013)의 연구에 의하면 수확시기별 파프리카의 비타민 $\mathrm{C}$ 함량은 $1,360.2-2,020.0 \mathrm{mg} / 100 \mathrm{~g}$ 으로 본 연구 결과와 비슷한 함량을 나타내었다. Deepa 등(2007)은 파프리카 10종의 비타민 C 함 량을 분석한 결과, $980-3,030 \mathrm{mg} / 100 \mathrm{~g}$ of dry weight의 범위로 품종에 따라서 함량 차이가 크게 났다고 보고하였고, Ghasemnezhad 등(2011)의 연구에서도 색이 다른 5가지 품종의 bell pepper의 비타민 C 함량 측정 결과, 품종별로 큰 차이가 났다고 보고하였다.

Chuah 등(2008)의 연구에 의하면 색상별 파프리카의 비타민 C 함량은 빨간색 파프리카 $(191 \mathrm{mg} / 100 \mathrm{~g}$ of fresh weight)가 가 장 높았고, 주황색 파프리카 $(163 \mathrm{mg} / 100 \mathrm{~g} \mathrm{FW})$ 그리고 노란색
파프리카 $(142 \mathrm{mg} / 100 \mathrm{~g} \mathrm{FW})$ 순으로 나타났다고 하였고, Kim 등(2016a)의 연구에서는 주황색 파프리카의 vitamin C 함량은 $116.29 \mathrm{mg} / 100 \mathrm{~g}$ 으로 가장 높았고, 노란색 파프리카(110.60 $\mathrm{mg} / 100 \mathrm{~g})$ 그리고 빨간색 파프리카 $(91.75 \mathrm{mg} / 100 \mathrm{~g})$ 순으로 나 타났다고 보고하였다. Kim 등(2018)의 연구에 의하면 빨간색 파프리카의 비타민 C 함량은 $44.89 \mathrm{mg} / 100 \mathrm{~g}$, 주황색 파프리카 $(75.29 \mathrm{mg} / 100 \mathrm{~g})$, 노란색 파프리카 $(42.09 \mathrm{mg} / 100 \mathrm{~g})$ 로 보고하 였다. 다른 연구 결과와 비교시, 파프리카는 색상에 따라 비타 민 C 함량에 차이를 나타내었다. 파프리카는 미성숙된 상태에 서는 녹색이고, 과실이 익어가면서 품종에 따라 빨간색, 노란색 및 주황색 등 다양한 색으로 변하며(Kim et al., 2011a), 파프리 카가 성숙되면 비타민 C 함량이 증가하는데(Chuah et al., 2008), 비타민 C 함량이 높은 것은 일조량과 관련이 있다고 하 였다(Mozafar, 1994). 따라서 비타민 C의 경우 햇빛의 양 및 재 배 조건에 많은 영향을 받아 색에 의한 영향보다는 재배 환경 에 더 영향을 받는 것으로 보인다.

Table 6. Vitamin content of colored paprika in Korea $(\mathrm{mg} / 100 \mathrm{~g}$ of dry weight)

\begin{tabular}{cccc}
\hline & RP & OP & YP \\
\hline Vitamin C & $1,302.47 \pm 9.73^{\mathrm{b}}$ & $1,234.79 \pm 61.68^{\mathrm{b}}$ & $1,466.86 \pm 15.58^{\mathrm{a}}$ \\
Vitamin E & $18.01 \pm 0.30^{\mathrm{a}}$ & $12.40 \pm 0.43^{\mathrm{b}}$ & $11.90 \pm 0.32^{\mathrm{b}}$ \\
\hline
\end{tabular}

Each result is expressed as the mean \pm SD.

Different superscripts in the same row are significantly different at $\not<0.05$ by Duncan's multiple range test.

$\mathrm{RP}$, red paprika; OP, orange paprika; YP, yellow paprika. 
Table 7. Mineral content of colored paprika in Korea $(\mathrm{mg} / 100 \mathrm{~g}$ of dry weight)

\begin{tabular}{cccr}
\hline & $\mathrm{RP}$ & $\mathrm{OP}$ & \multicolumn{1}{c}{$\mathrm{YP}$} \\
\hline $\mathrm{Ca}$ & $49.51 \pm 0.00^{\mathrm{b}}$ & $58.97 \pm 1.10^{\mathrm{b}}$ & $91.99 \pm 7.10^{\mathrm{a}}$ \\
$\mathrm{Cu}$ & $0.2 \pm 0.0^{\mathrm{c}}$ & $0.41 \pm 0.01^{\mathrm{b}}$ & $0.55 \pm 0.00^{\mathrm{a}}$ \\
$\mathrm{Fe}$ & $3.7 \pm 0.0^{\mathrm{c}}$ & $4.65 \pm 0.03^{\mathrm{a}}$ & $4.12 \pm 0.01^{\mathrm{b}}$ \\
$\mathrm{K}$ & $2,152.17 \pm 17.91^{\mathrm{c}}$ & $2,440.30 \pm 57.81^{\mathrm{b}}$ & $2,704.78 \pm 7.90^{\mathrm{a}}$ \\
$\mathrm{Mg}$ & $106.78 \pm 0.42^{\mathrm{c}}$ & $112.70 \pm 0.22^{\mathrm{b}}$ & $116.60 \pm 0.66^{\mathrm{a}}$ \\
$\mathrm{Mn}$ & $1.14 \pm 0.00^{\mathrm{c}}$ & $1.30 \pm 0.00^{\mathrm{b}}$ & $1.65 \pm 0.01^{\mathrm{a}}$ \\
$\mathrm{Na}$ & $10.96 \pm 0.53^{\mathrm{a}}$ & $11.28 \pm 0.07^{\mathrm{a}}$ & $10.75 \pm 0.73^{\mathrm{a}}$ \\
$\mathrm{P}$ & $252.54 \pm 0.39^{\mathrm{c}}$ & $280.36 \pm 0.50^{\mathrm{b}}$ & $295.94 \pm 3.77^{\mathrm{a}}$ \\
$\mathrm{Zn}$ & $2.11 \pm 0.09^{\mathrm{b}}$ & $2.12 \pm 0.07^{\mathrm{b}}$ & $2.74 \pm 0.02^{\mathrm{a}}$ \\
\hline Total & $2,579.11$ & $2,912.09$ & $3,229.12$ \\
\hline
\end{tabular}

Each result is expressed as the mean \pm SD.

Different superscripts in the same row are significantly different at $\not<0.05$ by Duncan's multiple range test.

$\mathrm{RP}$, red paprika; OP, orange paprika; YP, yellow paprika.

비타민 E의 경우 RP가 $18.01 \mathrm{mg} / 100 \mathrm{~g}$ 으로 $\mathrm{OP}(12.40 \mathrm{mg} /$ $100 \mathrm{~g})$ 와 $\mathrm{YP}(11.90 \mathrm{mg} / 100 \mathrm{~g})$ 에 비해 유의적으로 높게 나타났 다. Kim 등(2017)의 연구에 의하면 빨간색 파프리카의 비타민 E함량은 $4.2 \mathrm{mg} / 100 \mathrm{~g}$, 초록색 파프리카의 비타민 E함량은 0.7 $\mathrm{mg} / 100 \mathrm{~g}$ 으로 보고하여 초록색보다 유색을 가진 파프리카에서 비타민 $\mathrm{E}$ 함량이 더 높은 것으로 보인다.

\section{유색 파프리카의 무기질}

유색 파프리카의 무기질 함량을 분석한 결과(Table 7), 칼륨의 함량이 2,152.17-2,704.78 mg/100 g으로 전체 무기질 중 약 $83 \%$ 를 차지하여 가장 높은 함량을 나타내었고, 인(252.54-295.94 mg/100 g) 그리고 마그네슘 $(106.78-116.60 \mathrm{mg} / 100 \mathrm{~g})$ 순으로 나타났다.

색상에 따라서는 칼륨의 경우 YP가 $2,704.78 \mathrm{mg} / 100 \mathrm{~g}$ 으로 유의적으로 가장 높은 함량을 나타내었고, $\mathrm{OP}(2,440.30 \mathrm{mg} / 100$ $\mathrm{g})$ 그리고 $\mathrm{RP}(2,152.17 \mathrm{mg} / 100 \mathrm{~g})$ 순으로 나타났다. 또한 인, 마그네슘도 YP가 RP와 OP에 비해 유의적으로 높은 함량을 나 타내었다. 무기질의 총 함량 또한 YP는 3,229.12 mg/100 g으로 가장 높았고, $\mathrm{OP}(2,912.09 \mathrm{mg} / 100 \mathrm{~g})$ 와 $\mathrm{RP}(2,579.11 \mathrm{mg} / 100 \mathrm{~g})$ 순으로 나타났다. Jeong 등(2006)에 의하면 파프리카 품종별 무 기성분 함량을 분석한 결과, 칼륨이 가장 많은 비중을 차지하 였다고 보고하였고, Kim 등(2016a)에서도 파프리카의 주요 무 기질은 칼륨으로 보고하여 본 연구 결과와 비슷한 결과를 나타 내었다. 본 연구결과, 무기질은 색에 따라 차이를 나타내었고, 노 란색을 띠는 파프리카일수록 함유량이 높은 것으로 사료된다.

\section{요약}

본 연구에서는 국내에서 재배중인 빨간색, 주황색 그리고 노 란색을 띠고 있는 3 가지의 유색 파프리카의 영양성분을 분석하
였다. 일반성분 측정 결과, 수분함량, 조지방 및 조단백은 색에 따른 유의적인 차이는 없었고, 조회분의 경우 $\mathrm{OP}$ 가 유의적으로 높게 나타났다. 파프리카의 주요 유리당은 fructose와 glucose로 나타났고, RP, YP 그리고 $\mathrm{OP}$ 순으로 유의적인 차이를 나타냈 으며 lactose와 maltose는 검출되지 않았다. 유기산은 citric acid 가 가장 높게 나타났으며, 특히 succinic acid의 경우 RP가 OP와 YP에 비해 3.6-5.3배 더 높게 나타났다. 파프리카를 구성하는 아미노산은 16종으로 주요 아미노산은 aspartic acid, glutamic acid 및 lysine로 전체 55.2\%-60.4\%를 나타냈고, OP가 RP와 YP보다 높은 경향을 나타내었다. 지방산은 6종의 포화 지방산 과 4종의 불포화 지방산이 함유되어 있었고, 포화 지방산 중 $57.8 \%-66.1 \%$ 를 차지하고 있는 palmitic acid의 경우 RP, YP 그 리고 OP 순으로 유의적인 차이가 있었다. 불포화 지방산 중 $57.9 \%-59.7 \%$ 를 차지하고 있는 linoleic acid의 경우 $\mathrm{YP}, \mathrm{OP}$ 그 리고 RP 순으로 유의적인 차이를 나타내었다. 비타민의 경우 수용성 비타민 C는 $\mathrm{YP}$ 가 가장 높았으며, 지용성 비타민 $\mathrm{E}$ 는 $\mathrm{RP}$ 가 가장 높게 나타났다. 무기질은 9종으로 potassium이 $83.4 \%-83.7 \%$ 를 차지하고 있었으며 $\mathrm{YP}, \mathrm{OP}$ 그리고 RP 순으로 유의적인 차이를 나타내었다. 따라서 연구 결과를 종합해 볼 때 3 가지 파프리카는 색상 차이에 의해 영양성분의 차이가 있 었고, 이를 활용하여 소비자의 소비에 영향을 줄 수 있는 지표 로서 활용될 수 있을 것으로 사료된다.

\section{Conflicts of Interest}

The authors declare no potential conflict of interest.

\section{Acknowledgments}

This research was also partially supported Export Promotion 
Technology Development Program (617068-05) by the Ministry of Agriculture, Food and Rural Affairs (Korea).

\section{Ethics Approval}

This article does not require IRB/IACUC approval because there are no human and animal participants

\section{Author Contributions}

Conceptualization: Choi HD

Data curation: Ryu AR, Kang MC

Formal analysis: Hong JS, Choi JH, Choi YS

Methodology: Ryu AR, Kang MC, Hong JS, Choi JH, Choi YS, Choi HD

Software: Ryu AR, Kang MC

Validation: Choi YS, Choi HD

Investigation: Ryu AR, Kang MC, Hong JS, Choi JH, Choi YS, Choi HD

Writing - original draft: Ryu AR, Kang MC, Hong JS, Choi JH, Choi HD

Writing - review \& editing: Ryu AR, Kang MC, Hong JS, Choi JH, Choi YS, Choi HD

\section{Author Information}

A-Reum Ryu (Researcher, Korea Food Research Institute) https://orcid.org/0000-0002-4666-0501

Min-Cheol Kang (Senior Researcher, Korea Food Research Institute) https://orcid.org/0000-0002-9658-9045

Jung Sun Hong (Senior Researcher, Korea Food Research Institute) https://orcid.org/0000-0002-0849-8478

Jeong Hee Choi (Principal Researcher, Korea Food Research Institute) https://orcid.org/0000-0003-1265-2308

Yun-Sang Choi (Principal Researcher, Korea Food Research Institute) https://orcid.org/0000-0001-8060-6237

Hee-Don Choi (Principal Researcher, Korea Food Research Institute) http://orcid.org/0000-0001-8973-0330

\section{References}

AOAC. 2000. Official methods of analysis of AOAC International. $17^{\text {th }}$ ed. AOAC International. Gaithersburg, MD, USA. pp 33-36.

Bae SJ, Song MH, Oh JY, Bae JT, Kim JH, Lee GS. 2018. Development of cosmetic ingredient by fermented paprika juice. J Soc Cosmet Sci Korea 44:117-124.
Baenas N, Belović M, Ilic N, Moreno DA, García-Viguera C. 2019. Industrial use of pepper (Capsicum annum L.) derived products: technological benefits and biological advantages. Food Chem 274:872-885.

Choi E, Kim E, Lee Y. 2020. Anti-inflammatory effects of paprika fruit and leaf through heme oxygenase-1 induction in RAW264.7 macrophages. J Korean Soc Food Nutr 49:578-585.

Chuah AM, Lee YC, Yamaguchi T, Takamura H, Yin LJ, Matoba T. 2008. Effect of cooking on the antioxidant properties of coloured peppers. Food Chem 111:20-28.

Deepa N, Kaur C, George B, Singh B, Kapoor HC. 2007. Antioxidant constituents in some sweet pepper (Capsicum annuum L.) genotypes during maturity. Food Sci Technol 40:121-129.

Faustino JMF, Barroca MJ, Guiné RPF. 2007. Study of the drying kinetics of green bell pepper and chemical characterization. Food Bioprod Process 85:163-170.

Ghasemnezhad M, Sherafati M, Payvast GA. 2011. Variation in phenolic compounds, ascorbic acid and antioxidant activity of five coloured bell pepper (Capsicum annum) fruits at two different harvest times. J Funct Foods 3:44-49.

Ha TM, Won SY, Seo J, Kang HY, Lee DH, Keuyn YH. 2019. Analysis of free sugars contents of fruit and fruit vegetables classified by cultivar and cultivation area. Korean J Food Nutr 32:321-327.

Jeong CH, Ko WH, Cho JR, Ahn CG, Shim KH. 2006. Chemical components of Korean paprika according to cultivars. Korean J Food Preserv 13:43-49.

Joung KH, Jin HJ, An JU, Yoon HS, Oh SS, Lim CS, Um YC, Kim HD, Hong KP, Park SM. 2018. Analysis of growth characteristics and yield pattern of 'Cupra' and 'Fiesta' paprika for yield prediction. J Bio-Environ Control 27:349-355.

Jung HA, Hong JY. 2017. Change in quality characteristics of yellow paprika according to drying methods. Korean $\mathrm{J}$ Food Preserv 24:1079-1087.

Kang JW, Lee SJ, Ahn BY. 2021. Inhibitory effects of ethanol extract of red sweet pepper (Capsicum annuum L.) on triglyceride biosynthesis in Rhodosporidium toruloides. Korean J Plant Res 34:186-196.

Kaur R, Kaur K, Ahluwalia P. 2020. Effect of drying temperatures and storage on chemical and bioactive 
attributes of dried tomato and sweet pepper. LWT-Food Sci Technol 117:108604.

Kim GP, Kang IK, Hwang YS, Park K, Choi Y, Choung MG. 2018. Changes in water-soluble vitamin contents in response to different processing methods in various paprika cultivars. Hortic Sci Technol 36:766-775.

Kim H, Hwang JB, Kim SN, Choi Y, Kim SM, Han HK, Yang MR, Kim HR. 2016a. Changes of nutrient composition and retention rate of sweet pepper by different types and blanching method. Korean J Food Cook Sci 32:433-440.

Kim HY, Kim H, Chun J, Chung H. 2017. Changes in $\beta$-carotene, vitamin $\mathrm{E}$, and folate compositions and retention rates of pepper and paprika by color and cooking method. J Korean Soc Food Sci Nutr 46:713-720.

Kim JS, An CG, Park JS, Lim YP, Kim S. 2016b. Carotenoid profiling from 27 types of paprika (Capsicum annuum L.) with different colors, shapes, and cultivation methods. Food Chem 201:64-71.

Kim JS, Ahn J, Lee SJ, Moon B, Ha TY, Kim S. 2011b. Phytochemicals and antioxidant activity of fruits and leaves of paprika (Capsicum Annuum L., var. special) cultivated in Korea. J Food Sci 76:C193-C198.

Kim JS, Ahn JY, Ha TY, Rhee HC, Kim SA. 2011a. Comparison of phytochemical and antioxidant activities in different color stages and varieties of paprika harvested in Korea. Korean J Food Sci Technol 43:564-569.

Kim JS, Lee WM, Rhee HC, Kim S. 2016c. Red paprika (Capsicum annuum L.) and its main carotenoids, capsanthin and $\beta$-carotene, prevent hydrogen peroxide-induced inhibition of gap-junction intercellular communication. Chem Biol Interact 254:146-155.

Lee SM, Kim JS, An CG, Park JS, Kim S. 2016. Assessment of paprika quality by instrumental parameters and sensory attributes. J East Asian Soc Diet Life 26:34-43.
Martín A, Hernández A, Aranda E, Casquete R, Velázquez R, Bartolomé T, Córdoba MG. 2017. Impact of volatile composition on the sensorial attributes of dried paprikas. Food Res Int 100:691-697.

Matsufuji H, Nakamura H, Chino M, Takeda M. 1998. Antioxidant activity of capsanthin and the fatty acid esters in paprika (Capsicum annuum). J Agric Food Chem 46:3468-3472.

Mozafar A. 1994. Plant vitamins: agronomic, physiological and nutritional aspects. CRC Press, Boca Raton, FL, USA. p 412.

Park BK, Kim SH, Ye EY, Lee HJ, Seo SJ, Kwon SH, Song SM, Joo KS, Heo MJ. 2020. A study on the safety of powdered agricultural products in Incheon. J Food Hyg Saf 35:136-145.

Park LY, Woo DI, Lee SW, Kang HM, Lee SH. 2014. Quality characteristics of Yanggaeng added with different forms and concentrations of fresh paprika. J Korean Soc Food Sci Nutr 43:729-734.

Sun T, Xu Z, Wu CT, Janes M, Prinyawiwatkul W, No HK. 2007. Antioxidant activities of different colored sweet bell peppers (Capsicum annuum L.). J Food Sci 72:S98-S102.

Topuz A, Feng H, Kushad M. 2009. The effect of drying method and storage on color characteristics of paprika. LWT-Food Sci Technol 42:1667-1673.

Zaki N, Hakmaoui A, Ouatmane A, Fernandez-Trujillo JP. 2013. Quality characteristics of Moroccan sweet paprika (Capsicum annuum L.) at different sampling times. Food Sci Technol 33:577-585.

(c) Copyright. Korean Society for Food Science of Animal Resources.

Date Received Oct. 13, 2021 Date Revised Oct. 21, 2021

Date Accepted Oct. 22, 2021 